by Vandana Prasad ${ }^{1 *}$, Prem Raj Uddandam ${ }^{1,2}$, Shailesh Agrawal $^{1}$, Sunil Bajpai ${ }^{3}$, Indrabir Singh ${ }^{4}$ Ashish K Mishra ${ }^{1,2}$, Anupam Sharma ${ }^{1}$, Madhav Kumar ${ }^{1}$ and Poonam Verma ${ }^{1}$

\title{
Biostratigraphy, palaeoenvironment and sea level changes during pre-collisional (Palaeocene) phase of the Indian plate: palynological evidence from Akli Formation in Giral Lignite Mine, Barmer Basin, Rajasthan, Western India
}

\author{
1. Birbal Sahni Institute of Palaeosciences, 53, University Road, Lucknow, 226007, India. \\ 2. Department of Geology, Banaras Hindu University, Varanasi, 221005. \\ 3. Department of Earth Sciences, Indian Institute of Technology, Roorkee, Uttarakhand, 247667, India. \\ 4.17-11-2C Metro City Nishat Ganj, Lucknow 226007, India.
}

(Received : 08/05/2019; Revised accepted : 09/10/2019)

https://doi.org/10.18814/epiiugs/2020/020030

Giral Lignite Mine succession (Akli Formation) from Barmer Basin, Rajasthan yielded rich assemblage of dinoflagellate cysts and compared with the global dinoflagellate zonation schemes, and a DanianThanetian age is proposed. Within a precise biostratigraphic control, changes in the terrestrial and marine palynomorphs allowed the construction of relative sea level fluctuation curve and the development of depositonal succession in a sequence stratigraphic framework. Based on the lithological and palynological content, the Giral Lignite Mine succession is divided in to five units. Unit 1 (lower $7.8 \mathrm{~m}$ ) is interpreted as transgressive deposit formed in an open bay setting during rise in the relative sea level representing the Transgressive Systems Tract (TST). The age is Danian on the basis of dinoflagellate cyst assemblages. Unit 2 (16.5 m) consists of 5-6 laterally occurring lignite bands. It is deposited during decrease of sea level and increased detritus supply in essentially salt marsh environment during Highstand Systems Tract (HST). Unit 3 (3.42 m) is shallow marine facies of Thanetian age deposited in a restricted setting represents a Transgressive Systems Tract. Unit $4(0.9 \mathrm{~m})$ is marked by a return to coastal marsh depositional conditions, possibly representing a Highstand Systems Tract. The erosional surface at the top of Unit 4 is interpreted as a Sequence Boundary. Unit $5(9.3 \mathrm{~m})$ is highly oxydized and is devoid of any organic matter content. Two major marine flooding surfaces identified in the Giral Lignite Mine succession can be correlated with the Maximum Flooding Surfaces (MFS) at 60.7 Ma and 57.9 Ma corresponding to the eustatic curve. Based on the dinoflagellate biostratigraphy Danian- Thanetian age has been assigned to the lignite bearing succession of Giral Mine. Western Indian margin consist of large-scale lignite deposits in Kutch, Cambay and Rajasthan Basin. The proposed Danian-Thanetian age of lignite bearing succession of Giral Mine is much older than the late Thanetian-early Ypresian age of lignite successions of Cambay and Kutch Basins of Gujarat. The present study suggests a significantly diachronous development of lignite deposits on the western peninsular margin of India.

\section{Introduction}

The Mesozoic-Tertiary geological history of the Indian subcontinent is marked by several dramatic events in terms of the breakup of Gondwanaland, northward movement of the Indian plate, Deccan volcanism, its collision with Asia, the closing of the Tethys Ocean, and formation of the Himalayas (Chatterjee et al., 2017). Post Deccan volcanism at K-Pg boundary ( $\sim 65 \mathrm{Ma})$ and prior to Palaeocene-Eocene Thermal Maximum event at P-E boundary (55.5 $\mathrm{Ma}$ ), the Palaeocene period witnessed a rapid movement of the Indian plate from subequatorial to equatorial zone of southern hemisphere. Although the timing of India-Asia collision remains highly controversial, a collision age close to the Palaeocene-Eocene boundary (55.5 Ma) is accepted by many workers, and the Palaeocene is generally considered a period of pre-collision phase (Chatterjee et 
al., 2017). The validation of various palaeobiogeographic hypotheses for terrestrial biota of India and tropical Asia, requires documentation of fossil remains from the Palaeocene sequences of the Indian subcontinent prior to India-Asia collision. The pre-collision biotic history of India is not well understood due to the paucity of well preserved Palaeocene sedimentary deposits and the associated biota. In particular, it is rare to find complete or near-complete Palaeocene sedimentary records in the central and western Indian margin, probably due to large scale Deccan volcanic activity during Maastrichtian (Cretaceous)-Danian (Palaeocene) in the region. Well-developed Palaeocene deposits (Ranikot Formation) are present in the northern part of the western margin of the Indian plate, in the Indus basin in Pakistan (Fitzsimmons et al., 2005). In western India, Palaeocene deposits are known in land outcrops, e.g. from the Jaisalmer Basin as Sanu Formation and possibly the basal part of Khuiala Formation (Singh, 2007); Palana Formation in the Bikaner Basin; Matanomadh Formation in the Kutch Basin (Biswas, 1992) and subsurface deposits as Vagadkhol Formation (=Olpad Formation) in the Cambay Basin (Sudhakar and Basu, 1973). Lately, sediments of Palaeocene age are identified in subsurface of the Barmer Basin as Fatehgarh Formation, which is essentially a sandstone unit that makes up good reservoir rocks (Compton, 2009). A prolific hydrocarbon resource with 33 oil prone discoveries from the Barmer Basin in the last decade makes the region extremely significant for the study of early Palaeogene deposits in the region. Since the Barmer Basin is home to oil exploration studies, the sedimentological aspects and the source rock character of Barmer Basin have been extensively studied (Compton, 2009). Varied depositional environments were characterized in the subsurface of Barmer Basin comprising alluvial fans, lake, lagoons and fluvial channels etc (Compton, 2009). Freshwater environment was interpreted for the early Palaeocene deposit of Barmer Basin (Compton, 2009). However, few reports of marine fish records from Giral lignite succession (Rana et al., 2005) and shallow marine/ brackish water trace fossil records from the Fatehgarh Formation (Parihar et al., 20016) from the surface outcrops of Barmer Basin suggest marine influence during their deposition. These sediments are fine grained deposits, namely shale, carbonaceous shale. A careful study of palynology may help to identify marine signature. Organicwalled dinoflagellate cysts, due to their preservation in a wide spectrum of inner to outer neritic environments have been extensively used in the early Palaeogene biostratigraphic zonation schemes worldwide (eg. Brinkhuis et al., 1994; Bijl et al., 2011; Bowman et al., 2012). In the present study, surface exposures at Giral Lignite Mine are investigated for marine dinoflagellate cysts and palynomorphs. While widespread dinoflagellate zonation schemes have been proposed for the high and mid-latitudinal regions of both Northern and Southern Hemispheres, limited studies were present from the low latitude areas. It is hence necessary to have a more comprehensive record of dinoflagellate cysts of early Palaeocene from the paleo-equatorial region for the development of biostratigraphic zonation and for the correct assessment of depositional facies. The recorded dinoflagellate cysts were compared with the dinoflagellates of Niger Delta Basin and Tunisia from African margin (low latitudes), and other mid- and high-latitude areas. The low latitude dinoflagellate cyst biostratigraphy and biozones for early Palaeocene succession were constructed. The studied section is further interpreted in terms of parasequences and system tracts in response to sea level changes to provide a depositional framework for early Palaeocene deposits in Giral Lignite Mine succession of Barmer Basin. The study also tries to understand the relationship between Giral Lignite of Barmer Basin and other deposits on the western Indian margin.

\section{General Geology}

The Barmer Basin is a nearly $200 \mathrm{~km}$ long, $<40 \mathrm{~km}$ wide and $<6$ $\mathrm{km}$ deep, north-south asymmetric rift basin bounded by normal extensional faults that display both NNW-SSE and NNE-SSW orientations covering approximately $6800 \mathrm{~km}^{2}$ region between $24^{\circ} 58^{\prime}$ to $26^{\circ} 32^{\prime} \mathrm{N}$ Latitudes and $70^{\circ} 05^{\prime}$ to $72^{\circ} 52^{\prime} \mathrm{E}$ Longitudes in the Thar desert of western Rajasthan in northwest India (Fig. 1) (Compton, 2009; Kelly et al., 2014). The basin connects to the north across the buried Devikot High into the Jaisalmer Basin and, to the south, Cambay Basin via the Sanchor sub-Basin (Kaila et al., 1990; Bladon et al., 2015; Dolson et al., 2015). Alkaline volcanic rocks form the basement of Barmer Basin (Compton, 2009). Detailed stratigraphy of Barmer Basin is based on both outcrop mapping and subsurface data collection from seismic and exploration well cores and cuttings (Compton, 2009). Pre-rift, basin fill sediments include early Jurassic (Lathi Fm.) and early Cretaceous (Ghaggar-Hakkara Fm.) deposits followed by Deccan volcanics. The deposition in Barmer basin started during the main phase of rifting between the late Cretaceous (Maastrichtian) and Eocene (Dolson et al., 2015). Largely, the early Palaeogene sediments in Barmer Basin represent the synrift Basin fill succession (Compton, 2009; Kelly et al., 2014). Stratigraphic succession of the Barmer Basin has been summarized in table 1.

\section{Giral Lignite Mine}

Giral mine is situated about $40 \mathrm{~km}$ NNW of Barmer and located on the Barmer-Fatehgarh road in the central part of the Barmer Basin (Fig. 1B). The stratigraphic succession is about $50 \mathrm{~m}$ thick, made up of shales, carbonaceous shale, lignite and bentonitic clays (Fig. 2). The succession consists of 9-11 laterally pinching lignite seams approximately $30 \mathrm{~cm}-1 \mathrm{~m}$ thick (Fig. 2). The $8 \mathrm{~m}$ lower part of the succession is rich in shales, carbonaceous shale and silty clays (Fig. 3), the top surface of upper most lignite shows erosional features with $30 \mathrm{~cm}$ to $1 \mathrm{~m}$ deep channel cuttings can be traced laterally in the upper most lignite seam (Fig. 5). This is followed by 10-15 cm thick lateritic horizon (Fig. 6). The topmost part of the Giral Lignite Mine succession is $14 \mathrm{~m}$ thick bentonitic clay horizon (Fig. 6). The mine succession lacks sandy facies and body fossils.

\section{Lithology}

The Giral Lignite Mine succession consists of basically three lithologies.

Shale- It is fine grained brown coloured faint laminar lithology.

Carbonaceous Shale- It is fine grained shale with streaks and dispersed carbonaceous material.

Lignite- It is made up of carbonaceous material saturated to makes lignite seams.

These three lithologies are cyclically repeated making few meter thick parasequences, mainly shale, carbonaceous shale- lignite representing shallowing upward cycles. There are no body fossils in 
the succession thus it is difficult to subdivide the succession into meaningful units. As discussed below lithology, coupled with dinoflagellate and pollen spores has helped in identification of depositional environments, parasequences and stratigraphic units.

\section{Materials and Methods}

A total of 105 sediment samples were collected from the $38 \mathrm{~m}$ thick lignite bearing succession of Giral mine. For dinoflagellate study, the samples were prepared following the standard palynological technique including treatment with $10 \% \mathrm{HCl}$ to digest the carbonates, followed by $40 \% \mathrm{HF}$ to digest silicates and further followed by mild oxidation with $10 \% \mathrm{HNO}_{3}$ to remove excess amorphous organic matter. In order to remove humic substances $1 \%$ $\mathrm{KOH}$ solution was also used, and lastly, the washed samples were sieved with a $10 \mu \mathrm{m}$ mesh sieve. The residue was examined under a transmitted light microscope for organic content. Permanent slides were prepared by spreading a drop of maceral with polyvinyl alcohol on glass coverslips evenly. After drying, the coverslips were fixed on the glass slides with Canada balsam. Palynological content was examined using a DM 2500 Leica Microscope.

For carbon isotopic study, samples were powdered and treated with $5 \% \mathrm{HCl}$ to remove carbonate. Subsequently, acid and soluble salts were removed from the

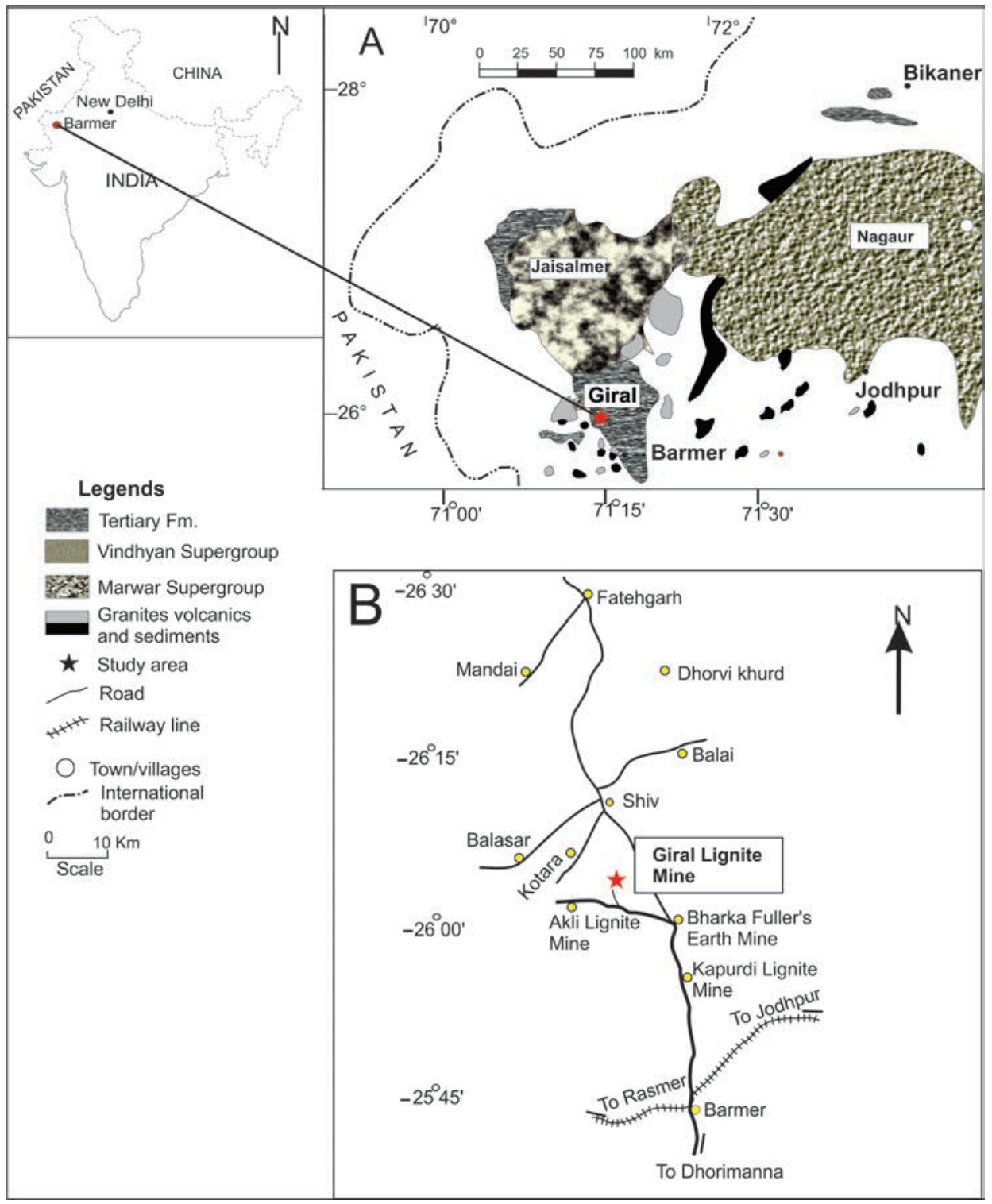

Figure 1. A- Geological map, B-locality map showing area of study.

sediments by centrifuging at $3000 \mathrm{rpm}$ and dried in an oven at $50^{\circ} \mathrm{C}$ and later crushed to fine powder. All the powdered and weighted samples were individually introduced into the pre-filled and conditioned reactor of Elemental Analyzer (Model no. Flash EA 2000

Table 1. Stratigraphic succession in Barmer basin after Compton, 2009.

\begin{tabular}{lll}
\hline SERIES & AGE & FORMATION \\
\hline \multirow{2}{*}{ EOCENE } & Priabonian & Nagarka \\
& Mid Lutetian & Arel \\
& Late Ypresian & Akli \\
& Early Ypresian & Thumbli \\
& Thanetian & DharviDunger \\
\hline PALEOCENE & Selandian & Barmer Hill \\
-------------------- UNCONFORMITY --------------- \\
& Danian & Fatehgarh \\
------------------- UNCONFORMITY ------------------- \\
\end{tabular}

$\mathrm{HT}$ ) through an auto sampler. The sample $\mathrm{CO}_{2}$ gas produced during combustion was introduced into MAT 253 Continuous Flow Isotope Ratio Mass Spectrometer (CFIRMS) coupled with ConFlow IV interface. Signals corresponding to masses 44,45 and 46 were measured for both sample and a reference gas, thereby calculating the isotopic compositions of individual samples. Reproducibility was also checked by repeat measurements. The tank $\mathrm{CO}_{2}$ was calibrated using international standard IAEA CH-3. Finally, two-point normalization technique (IAEA CH3 and IAEA CH6) has been used to convert all isotopic data into the isotopic reference scale i.e. VPDB. The long-term uncertainties associated with stable isotope analysis was $0.1 \%$.

\section{Results}

The present study is confined to the $38 \mathrm{~m}$ thick succession of shale, carbonaceous shales and lignite facies of Giral Lignite Mines. Based on the lithology and palynological content the $38 \mathrm{~m}$ succession was divided in to five Units. Unit 1 (Lower): $7.8 \mathrm{~m}$ thick from the base dominated by the shales, carbonaceous shales and silty shale 


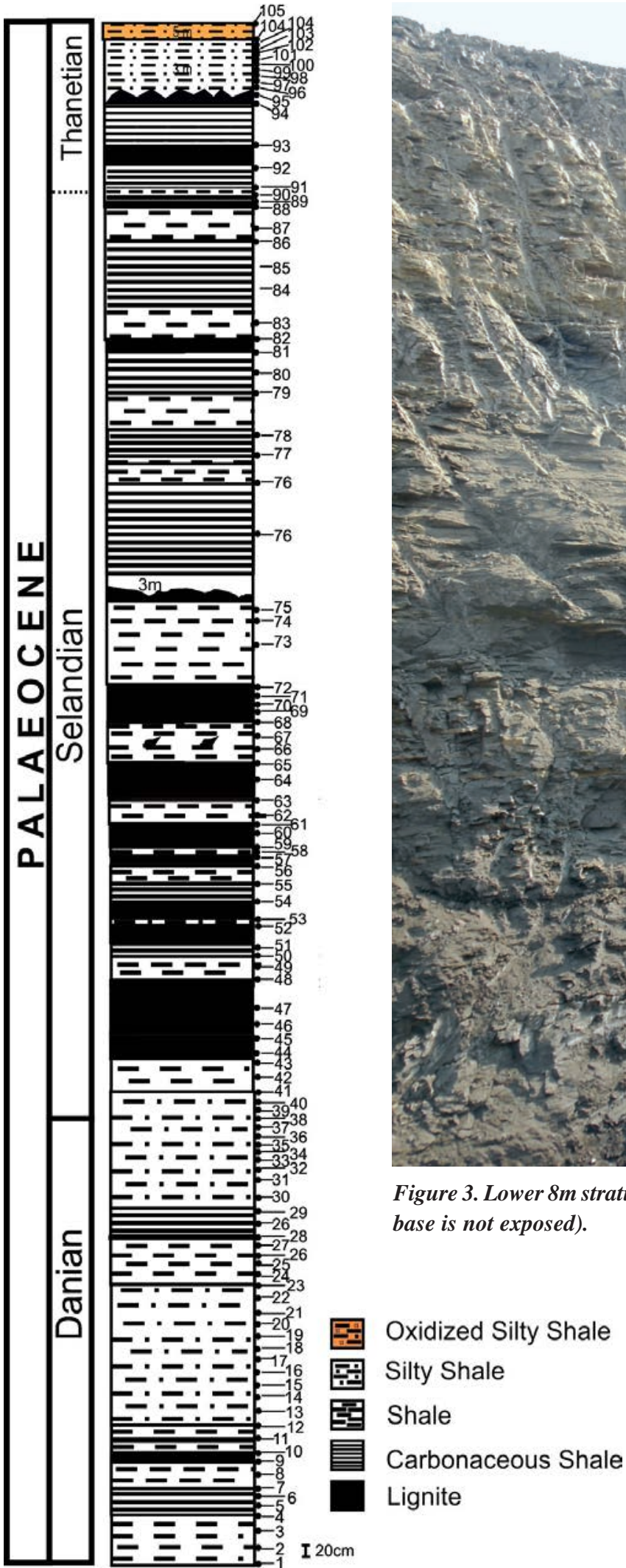

Figure 2. Stratigraphic section at Giral Lignite Mine showing the various lithology.

and contains large number of marine dinoflagellates and moderate number of terrestrial pollen and spores. Unit 2 (middle): $16.5 \mathrm{~m}$ thick (7.8-24.3 m) succession, only the lower part consisted of few dinoflagellate cysts while the rest of the Unit was dominated by mangrove and other terrestrial palynomorphs. Unit 3 (upper): $3.42 \mathrm{~m}$ thick (24.3-27.72 m) succession consisted of marine dinoflagellate cysts and mangrove pollen. Unit 4 (upper most): 0.9 m (27.72-28.62 $\mathrm{m})$ succession is the upper part of the section and the top part is lateritic in character. This Unit lacked marine dinoflagellate cysts but consisted of moderate number of terrestrial pollen and spore. Unit V $9.3 \mathrm{~m}$ (28.62-38 m) This Unit was devoid of both marine and terrestrial palynomorphs. Presence of dinoflagellate cysts in Unit 1 and Unit 3 indicate marine influence while Unit 2 and 4 contained only pollen and spore belonging to terrestrial and mangrove vegetation.

\section{Dinoflagellate Cysts Distribution}

Dinoflagellates are present in moderate numbers. Though the assemblage was characterized by low diversity of dinoflagellate cysts, good preservation and presence of age-diagnostic dinoflagellate cysts taxa helped in providing the biostratigraphic framework as well as age assessment of the Giral Lignite Mine succession. 
From $1.5 \mathrm{~m}$ from the base the Giral Lignite Mine succession is characterized by the LAD of Phelodinium tricuspe (Plate IV-c), Cerodinium striatum (Plate IV-e) and Trithyrodinium evittii (Plate

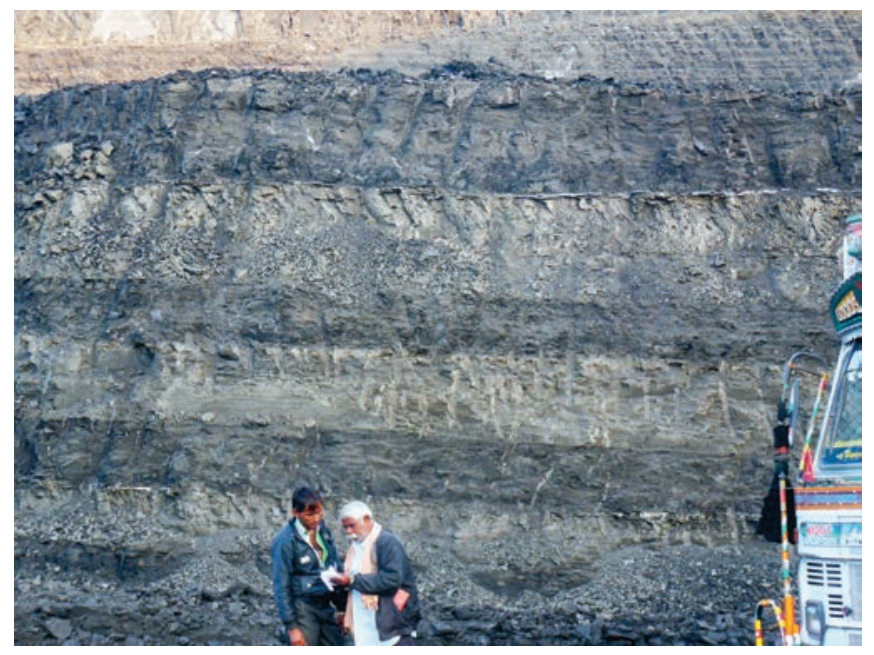

Figure 4. Stratigraphic Section at Giral Lignite Mine showing lignite seams.

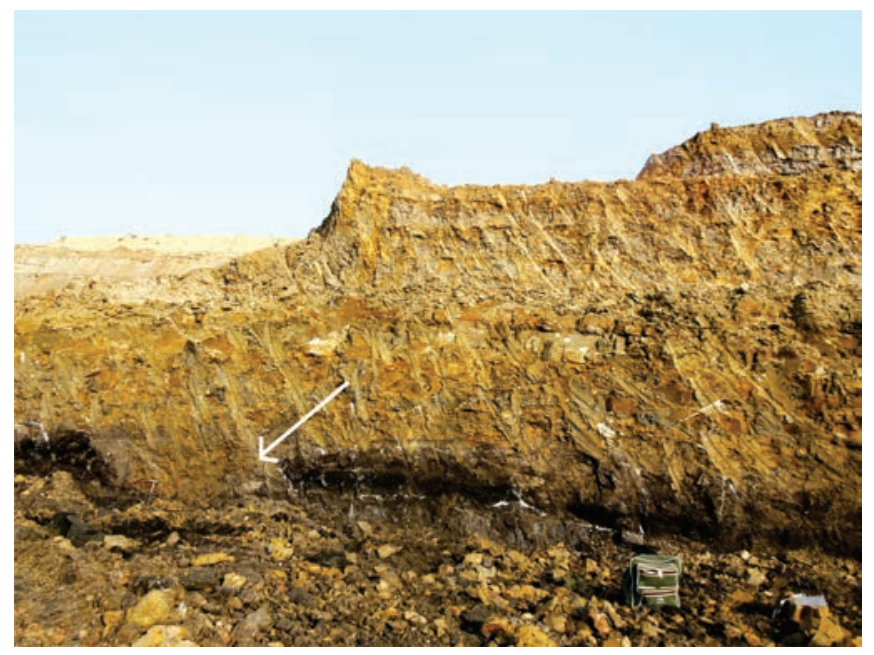

Figure 5. Stratigraphic Section at Giral Lignite Mine showing erosional features marked as arrow in the upper most lignite seam.

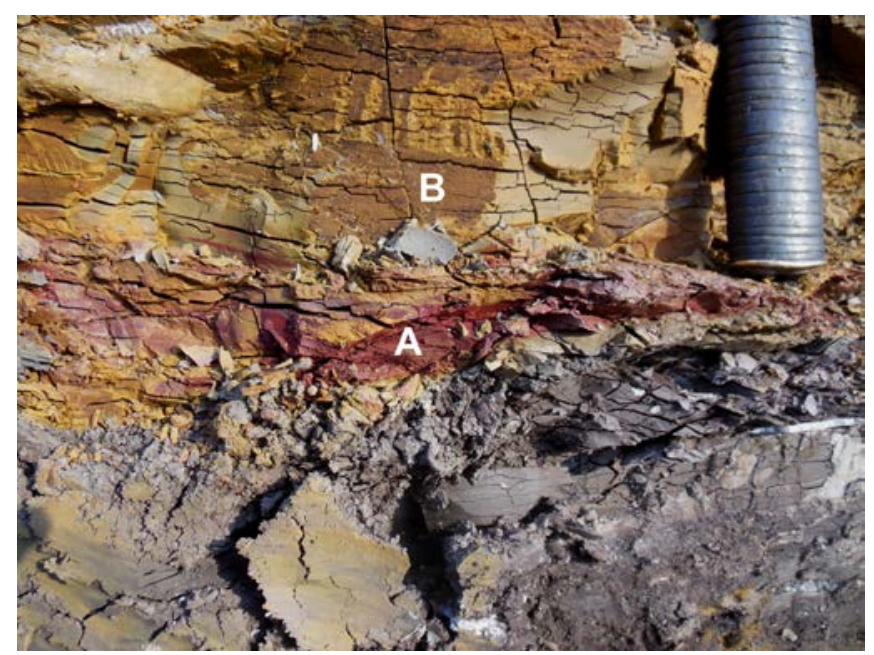

Figure 6. Upper most lignite seam showing laterite (A) and bentonitic clay $(B)$ in the upper part of Giral Lignite Mine.
IV-f) (Fig. 7). Phelodinium tricuspe had a geologic range known to terminate at the end of Cretaceous (Powell, 1992). LAD of Phelodinium tricuspe (Fig. 7) in the section pointed to latest Maastrichtian age. Trithyrodinium evittii first appeared in the Late Cretaceous Tethyan province but reached relatively high abundance in mid-to-high latitudes of both hemispheres just above the Cretaceous-Palaeogene boundary (Nøhr-Hansen and Dam 1997, Willumsen 2003; Slimani et al., 2010; Willumsen and Vajda, 2010). FAD of Trithyrodinium evittii in sample no 14 at $1.5 \mathrm{~m}$ from the base endorsed Danian age (Fig. 7). Cerodinium striatum has been found in majority of early Palaeogene successions in Europe (Powell, 1992); North Sea basin (Mudge and Bujak, 2001); Seymour Island, Antarctic Peninsula (Bowman et al., 2015); West Greenland (Nøhr-Hansen, 2003) and was restricted to Danian. LAD of Cerodinium striatum in the Unit 1 of the Giral section at $1.5 \mathrm{~m}$ from the base also pointed Danian age (Fig. 7). The LAD of Carpatella cornuta (Plate I-e,f), Damassadinium californicum (Plate I-b,c), Xenicodinium reticulatum (Plate III-a), Hafniasphaera graciosa (Plate V-c,d) and Lanternosphaeridium reinhardtii marked at $7.8 \mathrm{~m}$ height from the base in the section in sample no 38 (Fig. 7, Plate I, III, V). Damassadinium californicum and Carpatella cornuta are global marker for Danian as its FO marks the earliest Danian while its LO characterizes the latest Danian-beginning of Selandian (Slimani et al., 2010; Dastas et al., 2014). Both Damassadinium californicum and Carpatella cornuta made their first appearance in northern midlatitudes about 0.5 - 0.7 Ma after the end of the Cretaceous and their LAD marked the end of Danian. In the Giral mine succession their LAD was recorded at $7.8 \mathrm{~m}$ from the base in the shale horizon suggesting Danian-Selandian boundary (Fig. 7). Hafniasphaera cryptovesiculata, and Hafniasphaera graciosa have been recorded from the Danish basin above the K-Pg boundary in the early Danian (Hansen, 1977). In Giral mine, Hafniasphaera graciosa (Plate V$\mathrm{c}$,d) did not occur in the basal most level in the section but appeared at $6 \mathrm{~m}$ from the base its LAD at $7.8 \mathrm{~m}$ also indicated Danian age. The single occurrence of Xenicodinium reticulatum (Plate III-a) and Lanternosphaeridium reinhardtii, characteristic of Danian age (Hansen, 1977) present in sample no 38 in Giral mine also point to the Danian age. Spinidinium densispinatum and S. pilatum in Turtle Mountain Formation of Canada, Thyra Ø Formation of North Greenland, Ouled Haddou, southeastern Rif, Morocco, Chorrillo Chico Formation of southern Chile have been considered to be restricted to Danian age (Kurita and McIntyre, 1995; Lyck and Stemmerik, 2000; Quattrocchio and Sarjeant, 2003; Slimani et al., 2010). The consistent occurrence of Spinidinium species, $S$. densispinatum and S. pilatum, in throughout the unit 1 of Giral Lignite Mine also suggest Danian age (Fig. 7). The unit 1 is also characterized by the FAD of Exochosphaeridium bifidum (Fig. 7, Plate II-a), Spinidinium densispinatum, Magallanesium pilatum (Plate IV-g,h,i), Cordosphaeridium inodes (Plate II-b,e,f), Cordosphaeridium exilimurum (Plate I-h), Impletosphaeridium sp. (Plate I-g), Fibrocysta axialis (Plate II-c), Fibrocysta bipolar (Plate III-g,h), Hystrichokolpoma bulbosum (Plate II-i), Achmosphaera alcicornu (Plate IV-a), Apectodinium homomorphum and Apectodinium hyperacanthum (Plate V-a,b) along with several unidentified peridinioid species.

The $16.5 \mathrm{~m}$ thick Unit 2 succession is predominantly lignitebearing in Giral mine with 40-20 cm thick lignite bands, lower most part of which consisted of few Apectodinium homomorphum dinoflagellate cysts however, the lignite succession was devoid of any 


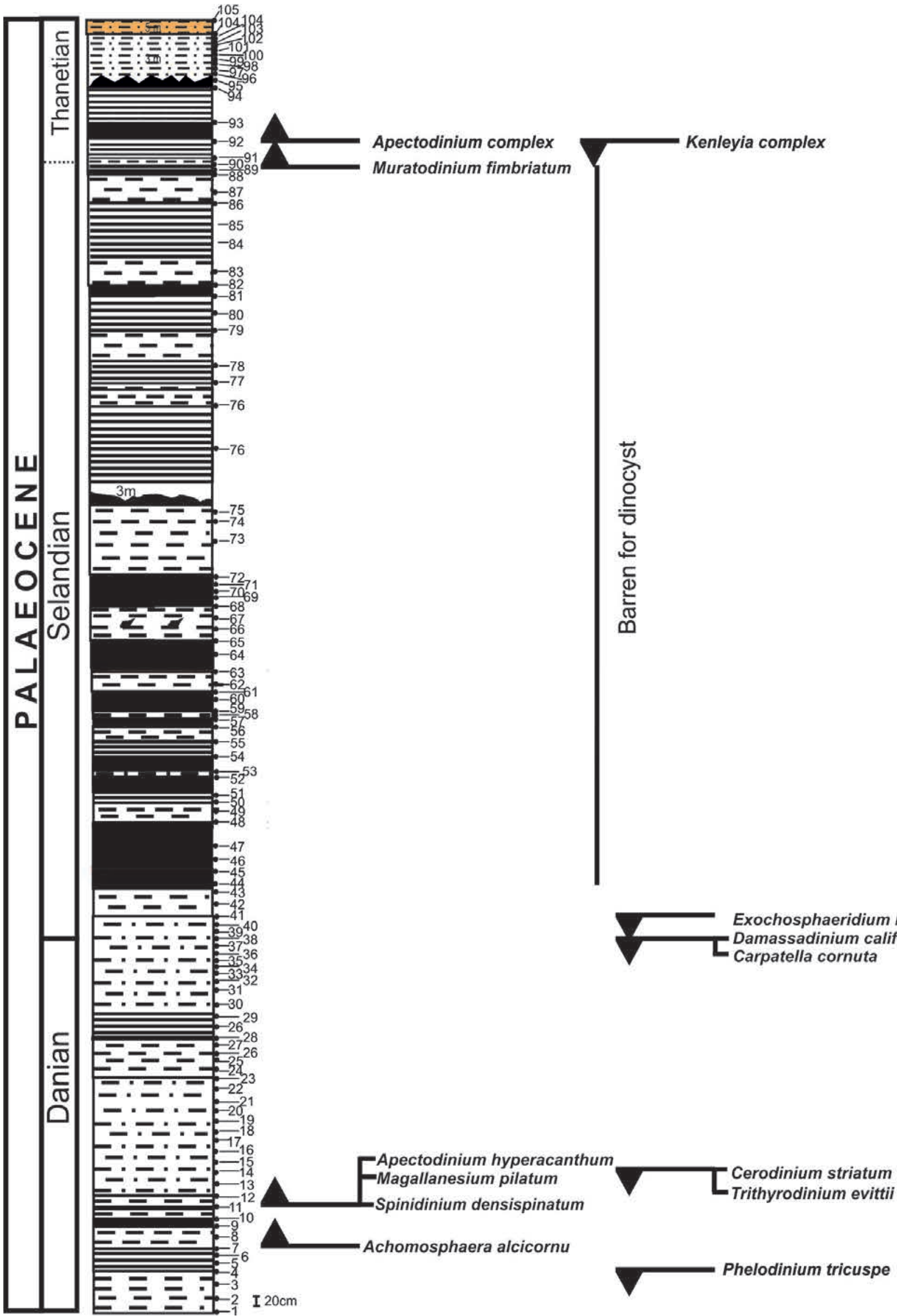

Figure 7. Litholog of the Giral Lignite succession with dinoflagellate cyst marker levels and age assignment of the studied succession. 
dinoflagellate cysts. The 3.42 m succession of Unit 3, above the lignite facies was characterized by the presence of several species of Kenleyia complex, Muratodinium fimbriatum, Turbiosphaera filosa and $T$. galatea dinocyst (Fig. 7, Plate I-i, III-b,i). Besides, Unit 3 also showed numerical abundance of Adnatosphaeridium multispinosum (Plate IIId), Cordosphaeridium inodes (Plate II-b,e,f), Cordosphaeridium exilimurum (Plate I-h), Fibrocysta bipolar (Plate III-g,h) and Apectodinium species (Fig, 7 Plate V-a,b). Except for the Muratodinium fimbriatum (Plate I-i) stratigraphic range of most of the dinocyst in the Unit 3 extended from Danian to Eocene. Muratodinium fimbriatum is a marker for late Palaeocene-early Eocene with its FAD at $~ 55 \mathrm{Ma}$ in the latest Palaeocene (Powell, 1992). M. fimbriatum has been recorded from late Palaeocene - early Eocene age stratigraphic sections of western India (Garg et al., 2008; Garg et al., 2011). High numerical abundances of Apectodinium hyperacanthum, A. homomorphum (Plate $\mathrm{V}$-a,b) in Unit 3 also point to late Thanetian age. Based on the stratigraphic ranges of various dinocyst species, a Late Thanetian age has been deciphered for Unit 3.

Comparison with the other latitudinal dinoflagellates assemblages dinocyst assemblages of present study were compared with the early Paleogene dinocyst records of low to mid latitudinal areas from the following localities: southern Nigeria, Anambra Basin (Antolinez and Oboh-Ikuenobe, 2007; Oboh-Ikuenobe et al., 2017); Morocco (Silmani et al., 2010); Colombia and Venezuela (Yepes, 2001); New Jersey shelf, Bass River (Sluijs et al., 2008, 2011); Anglo-Paris basin
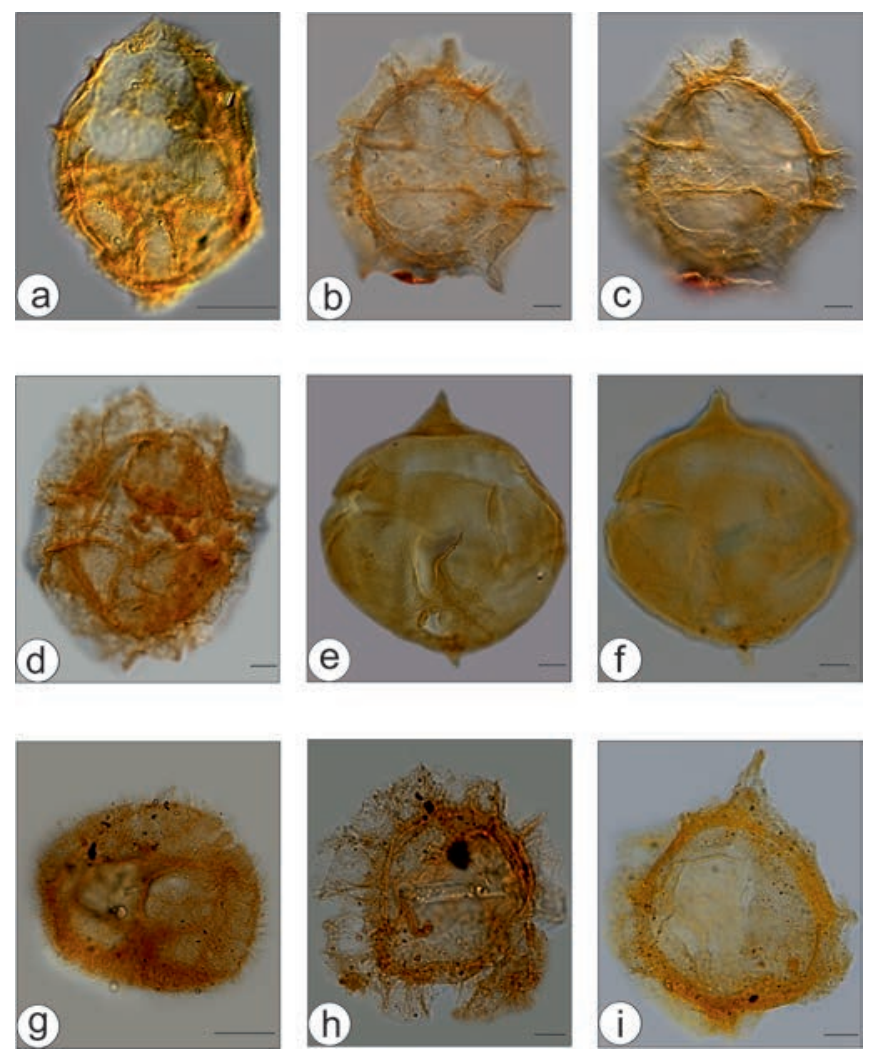

Plate I (scale bar 10 Hm). a-Damassadinium abbreviatum, Giral422 U 50-4, 16229; b,c-Damassadinium californicum, Giral36-1 J 35, 16250; d-Damassadinium californicum, Giral38-3 K 40-3, 16225; e,f-Carpatella connuta, Giral 38-6 W 53, 16246; gImpletosphaeridium implicatum, Giral 31-1 N 41-3, 16245; hCordosphaeridium exilimurum, Giral 38-3 036, 16225; iMuratodinium fimbriatum, Giral 37-1 M 32-2, 16236
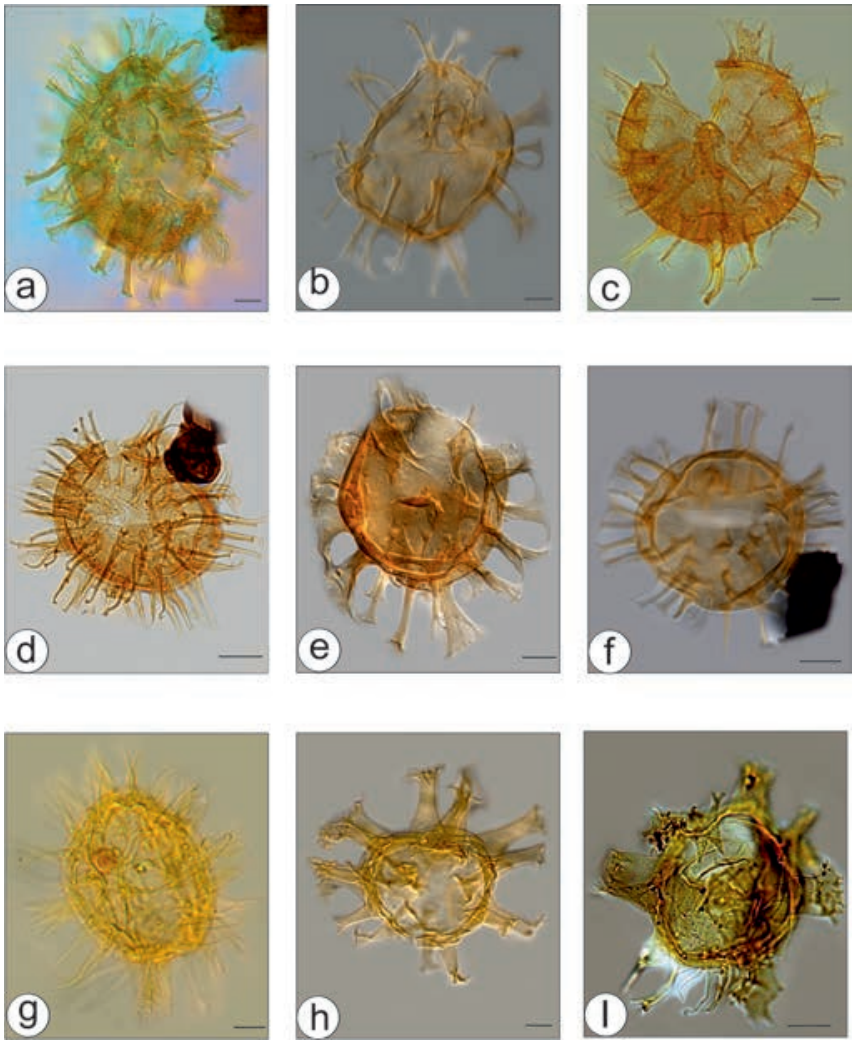

Plate II (scale bar $10 \mu \mathrm{m})$. a-Exochosphaeridium bifidum, Giral 38-2 Q 39, 16492; b-Cordosphaeridium inodes, Giral 29-n1 V 34, 16240; c-Fibrocysta axialis, Giral 26-1a $O$ 61, 16241; dOperculodinium sp., Giral 36-1N T 31, 16251; e-Cordosphaeridium inodes, Giral 38-n2 K 22-2, 16232; f-Cordosphaeridium inodes, Giral 29 n1 L 21-2, 16240; g-Diphys colligerum, Giral 40-1 F 244, 16231; h-Kleithriasphaeridium truncatum, Giral 14-5 L 45, 16234; i-Hystrichokolpoma sp., Giral 20-1 W 48, 16233

(Costa et al., 1978); Zululand, northern Natal, South Africa (Davey, 1969). Dinocyst records of both northern and southern high latitudes are preserved in the Seymour Island, Antarctica (Bowman et al., 2012), East Tasman Plateau (Brinkhuis et al., 2003; Williams et al., 2004); Tasmania (Bijl et al., 2011); southern Chile (Quattrachino et al., 2003); New Zealand (Crouch et al., 2014); Gippsland Basins, Australia (Helby, 1987); North Sea area (Powell 1988, Heilmannclausen 1994) northwest Europe (Mudge and Bujak, 1996), Western Siberia (Iakovleva, 2011), and Greenland (Nøhr-Hansen et al., 2011).

In the present study the dinoflagellate cyst species, Magallanesium pilatum, Cordosphaeridium inodes, Cordosphaeridium exilimurum, Impletosphaeridium sp., Fibrocysta axialis, Fibrocysta bipolar, Hystrichokolpoma bulbosum, Hafniasphaera spp., Turbiosphaera spp., Kenleyia spp are common to the early Palaeocene dinocyst assemblages of mid latitudinal regions from El Kef section, Tunisia (Brinhkhuis et al., 1994; Guasti et al., 2005); Kazakistan (Vasilyeva, 2013); Morocco (Silmani et al., 2010); New Jersey (Sluijs et al., 2008, 2011); Anglo Paris basin (Costa et al., 1978) Clayton Formation, Southeastern Missouri, USA (Dastas et al., 2014); and Georgia, U.S.A (Firth, 1987). The species that are common to high latitudes are Trithyrodinium evittii, Damassadinium californicum, Carpatella cornuta,Spinidinium densispinatum, Exochosphaeridium bifidum from Faeroe-shetland, British Isles (Mudge and Bujak,2001); Antarctica (Bowman et al., 2012). 

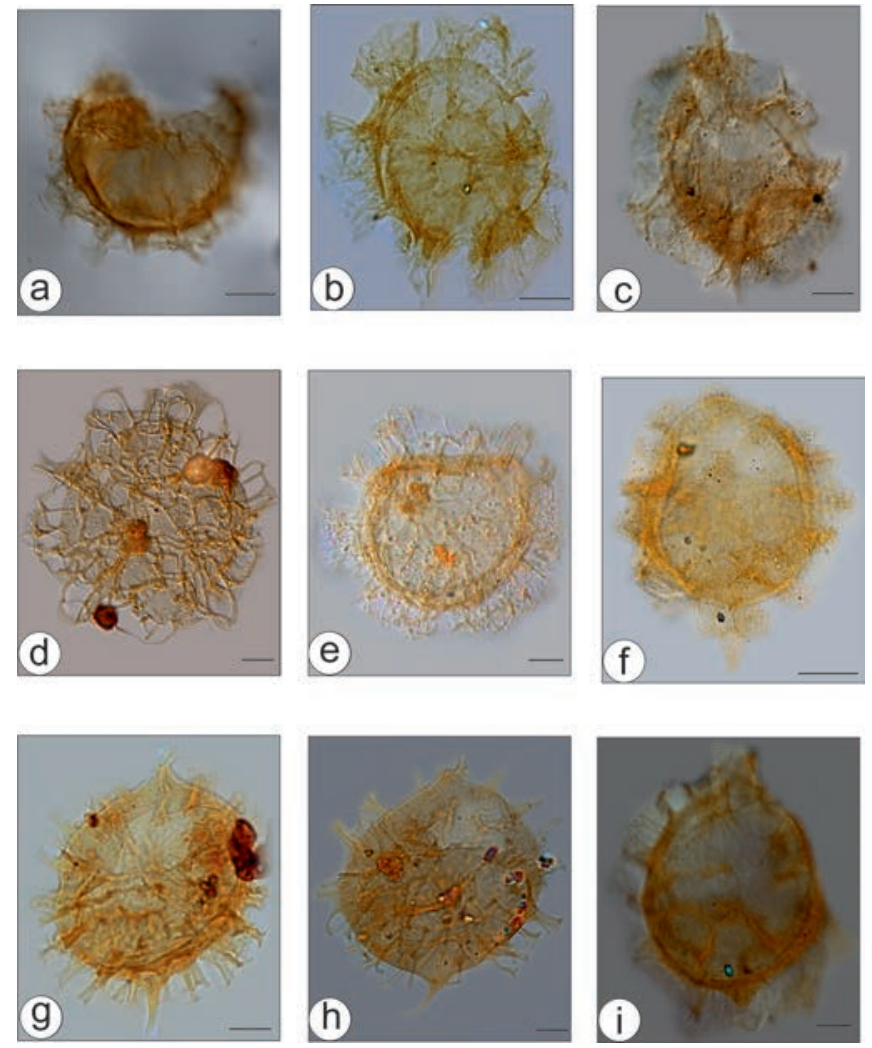

Plate III (scale bar $10 \mu \mathrm{m}$ ). a-Xenicodinium reticulatum, Giral261 S 37, 16241; b-Turbiosphaera filosa, Giral 91-4 K 33, 16247; cIfecysta pachyderma, Giral 38 n1 $N$ 43-3, 16249; dAdnatosphaeridium multispinosum, Giral 11-2 W 59-2, 16239; eGlaphyrocysta sp., Giral 17-1v T 47, 16235; f-Fibrocysta sp., Giral 31- 1 M 52, 16245; g-Fibrocysta bipolar, Giral 92-1 Q 51-3, 16248; h-Fibrocysta bipolar, Giral 91-4 R 27-2, 16247; i-Turbiosphaera galatea, Giral 91-4 U 46, 16247.

\section{Depositional framework and sequence stratigraphy}

Giral Lignite Mine succession is characterized by the fine-grained sediments. Sandy lithology is completely absent in this succession. Based on the lithology and microfossil characteristics the complete $38 \mathrm{~m}$ sedimentary succession of Lignite mine was divided in to five depositional units (Fig. 8, 9).

Unit 1 (7.8 m): This is mostly made up of repeated shale, lignite. Centimetre thick alterations of shale and carbonaceous shale successions with low to moderate occurrences of dinoflagellate cyst in the shale horizon suggest shallow marine restricted depositional conditions. Absence of any body fossils is indicative of prevalence of low-oxygen bottom water conditions. Palynological composition of Unit 1 showed fluctuating marine/terrestrial palynomorphs, providing evidence of small-scale sea-level fluctuations. Dinoflagellate cyst abundance and diversity in the shale layers were used to mark the flooding surfaces while the dominance of mangrove and freshwater pollen in the adjoining carbonaceous shale and lignite were indicative of progradational fill (Fig. 8). This type of small-scale sea-level cycles are very common and can be seen in the early Palaeogene sedimentary deposits of western India (Prasad et al., 2013). Unit 1 represents
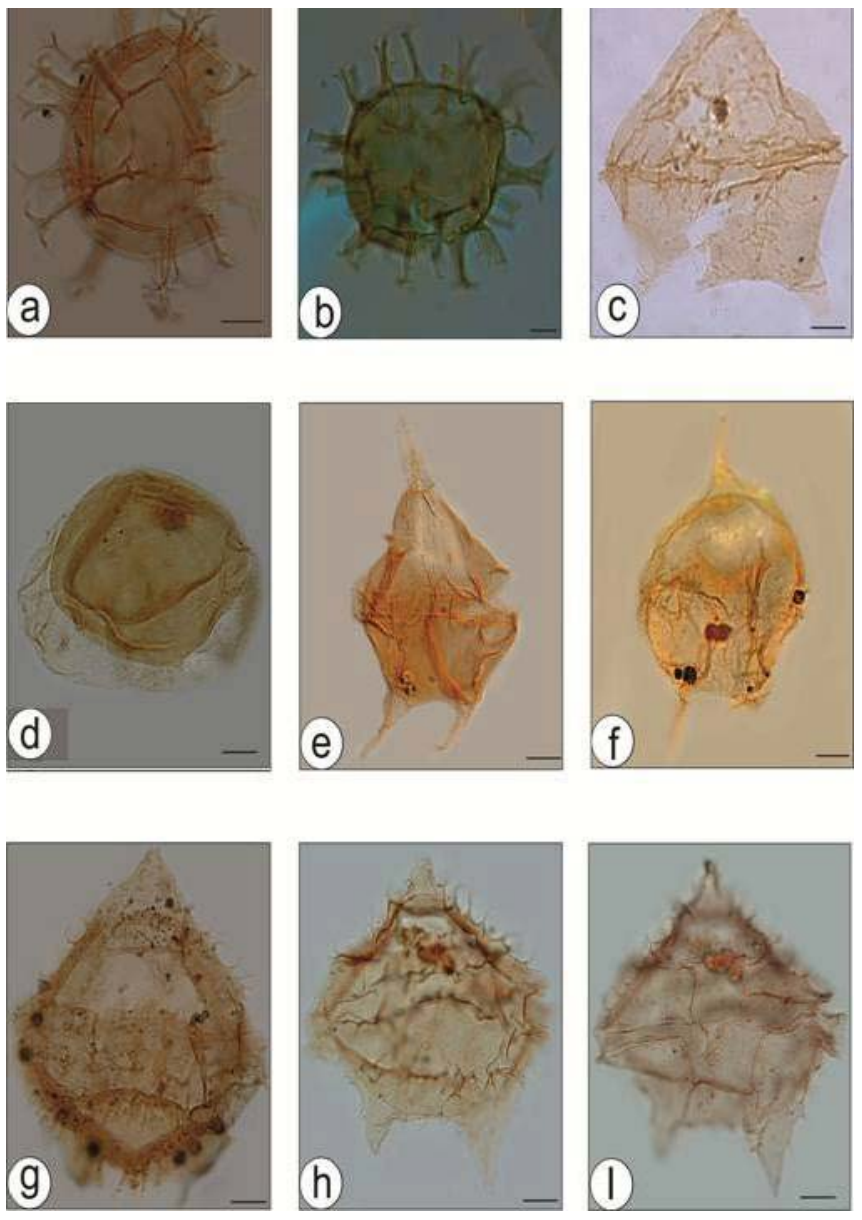

Plate IV (scale bar 10 um). a-Achomosphaera alcicornu, Giral 7-1 M 50, 16224; b-Cordospheridium inodes., Giral 38-3- G 37, 16243; c-Phelodinium tricuspe, Giral 04-1a 0 62, 16244; d-Thalassiphora pelagica, Giral 13-1- N 28-2, 16491; e-Cerodinium striatum, Giral 14-2 M 44-3, 16237; f-Trithirodinium evitii, Giral 262 H 57, 16228; g,Spinidinium densispinatum, Giral 11-2 L 42-2, 16239; h,iSpinidinium pilatum, Giral 11-2 $R$ 48, 16227

transgressive system tract with six small scale parasequences, with each successive parasequence culminating in increased marine influence (Fig. 8, 9). Sample no 38 at $7.8 \mathrm{~m}$ depth from the base show maximum diversity and concentration of dinoflagellate cyst and hence represent Maximum Flooding Surface (MFS). Below the LAD of Carpatella cornuta and Damassadinium californicum the maximum flooding surface at sample no 38 correlated well with the MFS at 60.7 Ma close to Danian-Selandian boundary of the Eustatic sea level curve (Hardenbol et al., 1998) (Fig. 9).

Unit 2 (7.8-24.3 m): consisted of carbonaceous shales, 5-6 lignite bands, and shale horizon. The unit start with decrease in the dinocyst diversity and abundance and it is replaced by numerical abundance of mangrove pollen indicating decrease in sea level and increased terrigenous supply from the land resulting in the development of salt marsh environment. Unit 2 thus represented Highstand Systems Tract. Cyclicity in the mangrove and freshwater pollen in the lignite facies provide evidence of repeated successions of mangrove marshes and fresh water marshes and provides evidence of small scale parasequences each becoming progressively more freshwater in character and thus represent small-scale sea-level cycles of the Highstand Systems Tract of Unit 2 (Fig. 9). 

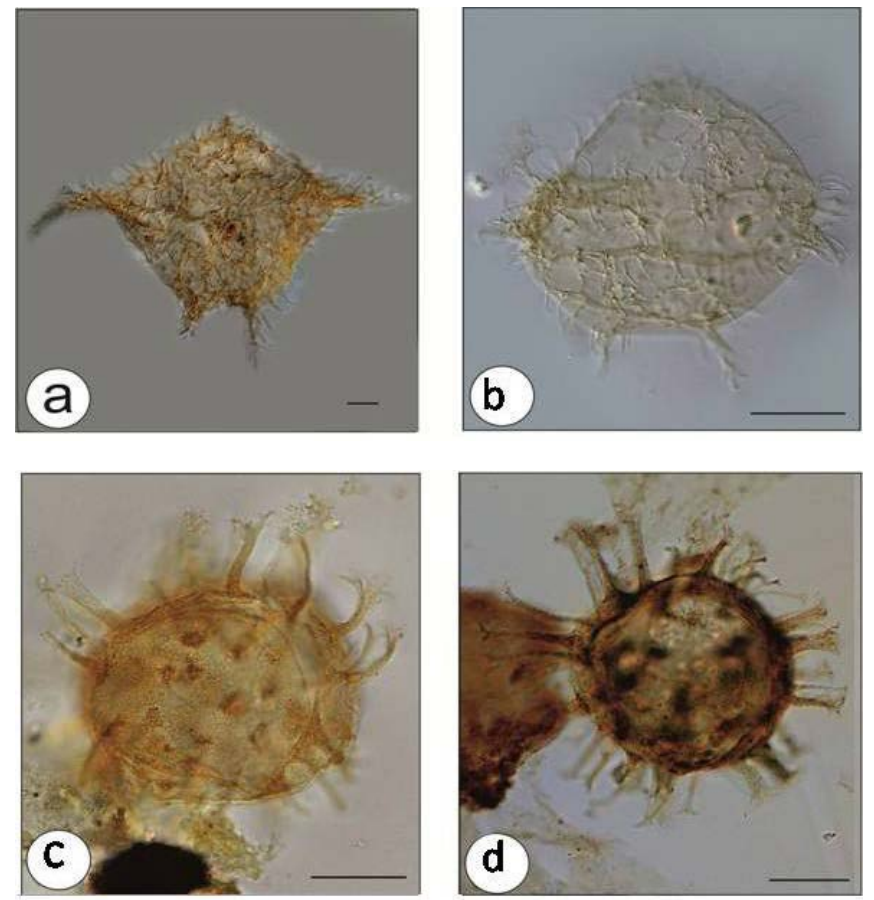

Plate V (scale bar $10 \mu \mathrm{m}$ ). a-Apectodinium hyperacanthum, Giral34-1 N52, 16242; b-A. homomorphum, Giral 34-1 M 50, 16242; c-Hafniasphaera graciosa, Giral 39-2-S 62-1, 16238; cHafniasphaera graciosa, Giral 34-1-R 38-3, 16242
Unit 3 (24.3-27.72 m): upper part of the Giral mine exhibits smallscale cycles of grey shale and carbonaceous shale. Dinoflagellate cysts and mangrove pollen dominate in this unit. In $3.2 \mathrm{~m}$ of Unit 3 consisted of two parasequences the top most parasequence culminated into more marine characteristics as it consists of maximum diversity and abundance of dinoflagellate cysts and thus considered corresponding to the Flooding Surface (FS). The FAD of $M$. fimbriatum in sample no 92 indicates Thanetian age (Fig. 7) hence it is possible that the flooding surface in sample no 92 corresponds to the MFS of Eustatic sea level cycle (Hardenbol et al., 1998) and represented the SelandianThanetian boundary (57.9Ma) (Fig. 9).

Unit 4 (27.72-28.62 m): It represents upperlignite horizon in Giral Mine. It consisted of one small-scale paraseqences of carbonaceousshale-lignite. The palynological details indicates cyclicity of mangrove swamp and fresh water swamp environment (Fig. 8, 9) providing evidence of lowering of sea level representing the progradational facies. The uppermost lignite band in this unit is rather freshwater in character. The top surface of this unit shows erosional features with 1-1.5 m deep channels (Fig. 5) It may be related to the lowering of the water table following aerial exposure. This erosional surface, represents a Sequence Boundary, resulting from a major sea level fall (Fig 9).

Unit 5 (28.62-38 m) Post Sequence Boundary, the $9.3 \mathrm{~m}$ succession is a highly oxydized yellow and red mottled lateritic facies (Fig. 6). It lacks well preserved organic matter probably due to aerial exposure and extensive weathering.

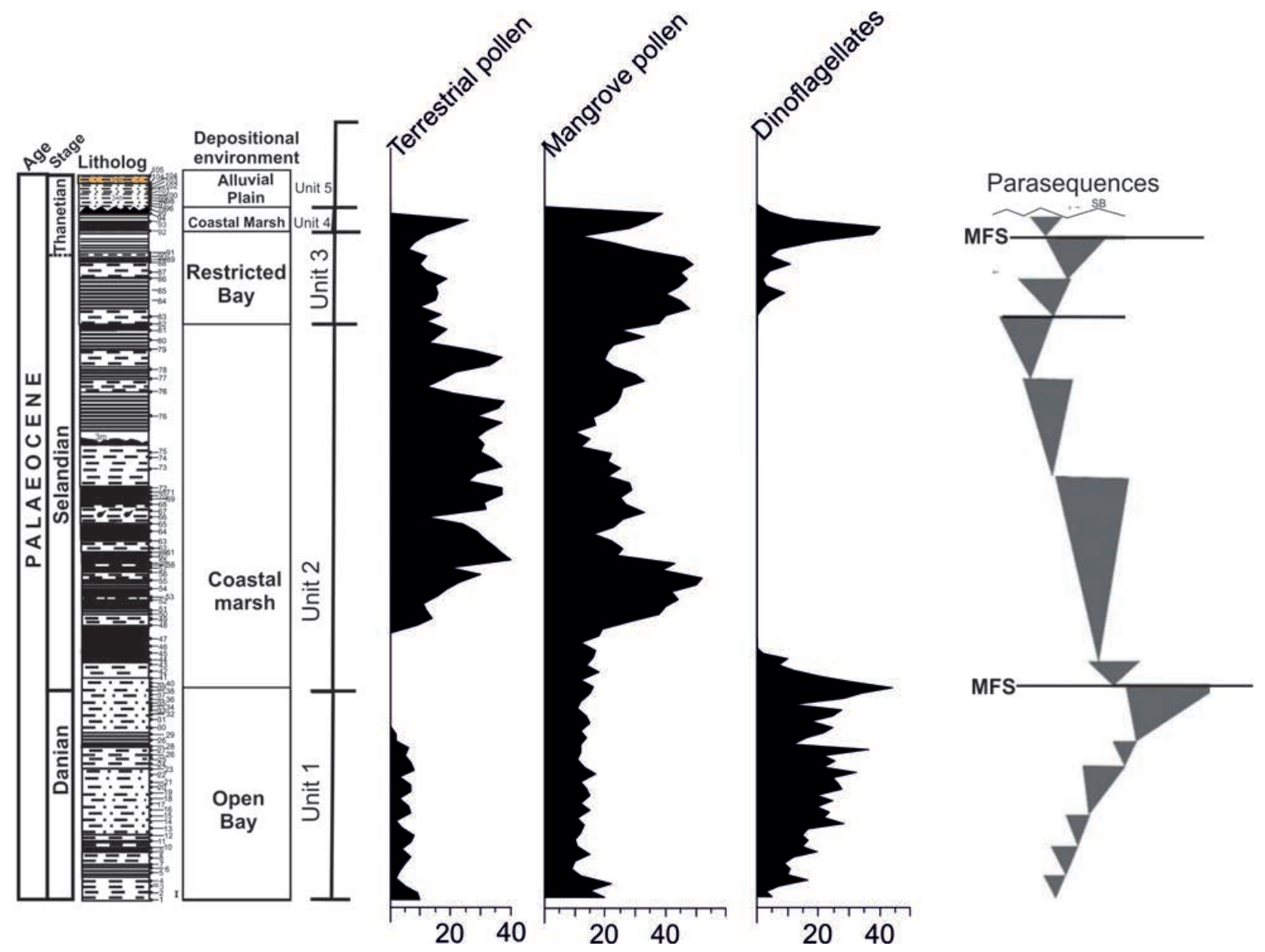

Figure 8. Litholog of the Giral Lignite succession, distribution pattern of terrestrial pollen, mangrove pollen and dinoflagellate cysts and parasequences. 

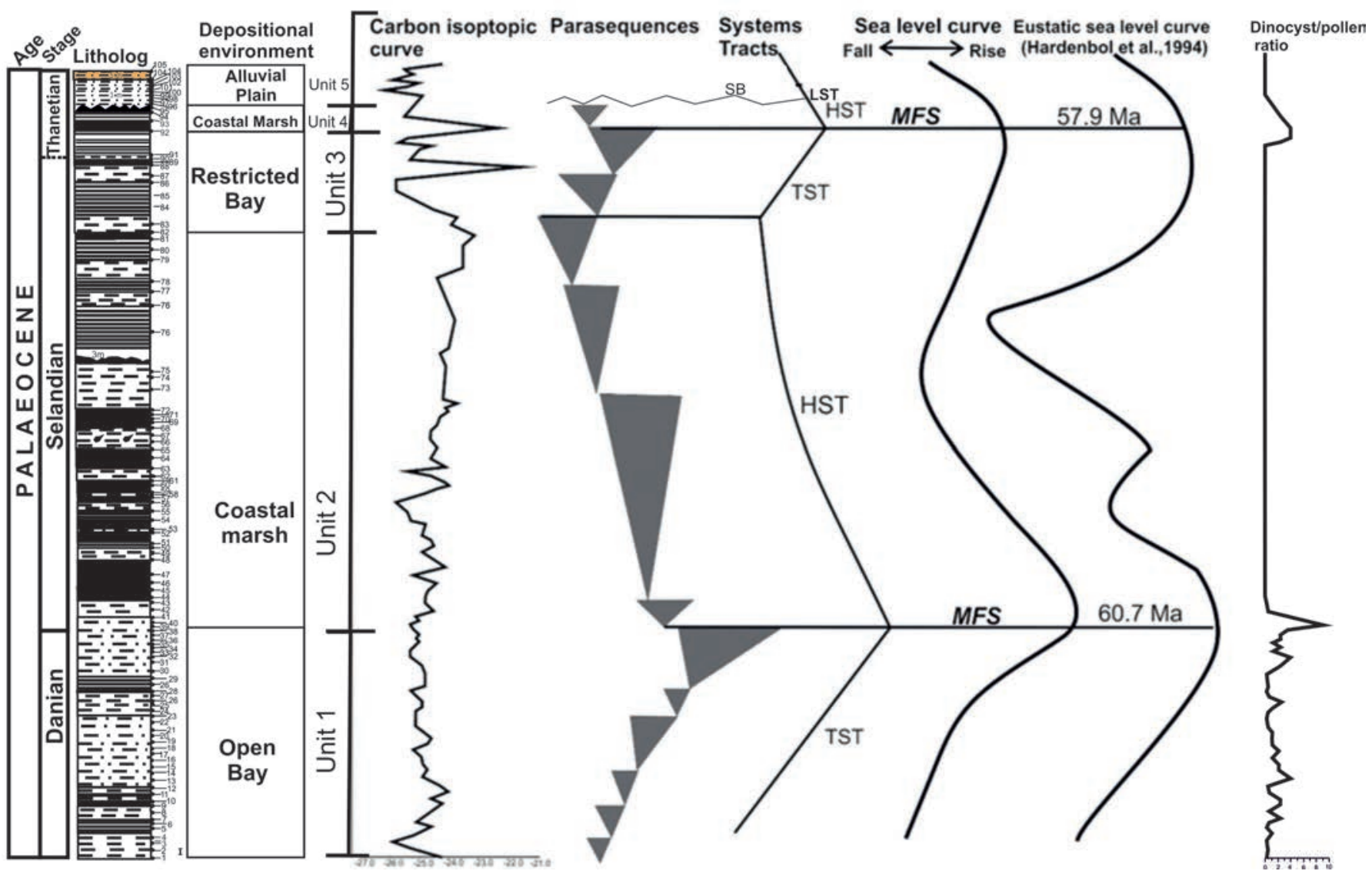

Figure 9. Giral Lignite succession, depositional environment, carbon isotopic curve, parasequences, systems tracts, sea level curve from this study, $3^{\text {rd }}$ order sea level curve after Hardenbol et al., (1994).

The $\delta^{13} \mathrm{C}$ values of samples in the Giral profile vary from -26.2 to $-21.5 \%$ (Table) covering a range of $4.7 \%$. The $\delta^{13} \mathrm{C}$ values show a distinct depth trend in the stratigraphic column (Fig.9). Three most pronounced decreasing trend in $\delta^{13} \mathrm{C}$ values occurred in sample no. $1-3$, sample no. 47-55 and sample no. 80-84. The bottom two gradual negative excursions have similar $1.7 \%$ magnitude whereas the third negative excursion shows $2.7 \%$ variation. These three negative carbon excursion trends are characterized by gradual recovery. The $\delta^{13} \mathrm{C}$ values from sample 17- 46 varying in narrow range whereas $\delta^{13} \mathrm{C}$ values at upper part shows large fluctuations.

\section{Discussion}

We interpret that the lower part of the Giral succession is a transgressive deposit that formed in an open bay setting during rise in sea level and hence represented the transgressive systems tract (TST). A relative sea level rise was also observed at Danian-Selandian boundary in Egypt, southern Tethyan margin (Speijer, 2003) as well as in North Sea basin (Steurbaut and Sztrákos, 2008). DanianSelandian boundary was placed at the top of Unit 1 below the LAD of D. californicum and C. cornuta (Fig. 7). The maximum diversity and richness of dinoflagellate cyst in this horizon indicated a MFS that coincided with the maximum transgression at $60.7 \mathrm{Ma}$ of the Eustatic sea level curve (Hardenbol et al., 1998) (Fig. 9). Due to the low energy and muddy nature of the depositional environment, there is no evidence of ravinement surfaces associated with the MFS. The Giral Lignite Mine succession, described under the Akli Formation, was assigned to the late Palaeocene-early Eocene age (Tripathi et al.,
2009). However, present dinoflagellate-based biostratigraphic analysis suggests an exclusively Palaeocene (Danian-Thanetian) age for the succession, with the intervening lignite seams being Selandian in age (Fig. 7, 9). The last appearance of dinoflagellate cysts Phelodinium tricuspe,Trithyrodinium evittii, Cerodinium striatum, and the first occurrence of global Danian marker Damassadinium californicum, Carpatella cornuta, Spinidinium densispinatum, endorse a Danian age to the lower $7.8 \mathrm{~m}$ of the section. Vastan Lignite Mine succession has been studied in detail for depositional environment, and biostratigraphy (Prasad et al., 2013). The lower part of Giral Lignite Mine take place in an open bay during marine transgression. The bay was filled up gradually and got converted into a coastal marsh complex during a slow fall of the relative sea level of highstand systems tract. Warm and humid, near equatorial climate with abundant precipitation led to the luxuriant growth of coastal marsh vegetation, and the development of lignite facies. Globally, the Selandian stage is interpreted to be coincident with a widespread rapid sea-level fall (Schmitz et al., 2008). The Highstand Systems Tract leads to LST. However, in the present study probably due to coastal area of depositional setting, the Lowstand deposit could not be developed. Following the development of lignite seams as part of the late HST, another transgressive deposit was characterized based on the presence of marine dinoflagellate cysts (Fig. 8, 9). Increased dinocyst diversity and abundance at the top of the succession was identified as flooding surface. The FAD of $M$. fimbriatum (i.e. Unit 3) endorse a basal Thanetian age correlated with the MFS at 57.9 Ma of Eustatic sea level curve of Hardenbol et al., 1998 (Fig. 9). The lignite-bearing horizon (i.e. Unit 4) in the upper part of Giral Lignite Mine was a 
progradational sequence representing a HST which ended with a major fall in the relative sea level (corresponding to Type 1 Sequence Boundary) (fig. 9) as evidenced by erosional features with 1-1.5 m deep channels indicating lowering of water table following an aerial exposure (Fig. 5, 6).

The Danian-Thanetian age of Giral succession is different from other late Thanetian-early Ypresian lignite successions from Cambay and Kutch basins. This suggests a significantly diachronous nature of lignite beds in different rift basins in the western Indian margin. The western Indian margin, during late Cretaceous-early Palaeogene was passive margin system. However, movement of Indian plate on Reunion Plume reactivated earlier formed intracratonic rifts, resulted in the development of large-scale rift basins in western India during the period (Sharma, 2007). Multiple factors during late Cretaceousearly Palaeogene governed the sedimentation pattern in rift basins of western Indian margin. Hence signatures of Eustatic sea level fluctuation in these rift basins depend on number of factors including the extent, thickness and temporal span of pre-existing Deccan basaltic rock's, distance from the sea, sediment supply due to local tectonic movement, and climate. These factors may not be in synchrony in inter-basinal regions hence the sedimentation pattern in different basins may vary in time and scale. The carbon isotopic composition of organic matter associated sediments is determined by in situ vegetation. Hence, $\delta^{13} \mathrm{C}$ values of SOM have been used to reconstruct paleovegetation history of the area. The $\delta^{13} \mathrm{C}$ values of $\mathrm{C}_{3}$ plants are mainly affected by environmental changes like temperature, humidity, availability of soil water, atmospheric $\mathrm{CO}_{2}$ concentration. These entire climatic factors influence stomatal conductance alter the $\delta^{13} \mathrm{C}$ values of plants. Therefore, $\delta^{13} \mathrm{C}$ values of these plants can also be used to climatic variations. The $\delta^{13} \mathrm{C}$ values of Giral Lignite Mine profile ranged from -26.2 to $-21.5 \%$ (Fig. 9). These values suggest organic carbon is derived exclusively from $\mathrm{C}_{3}$ vegetation. The variations in $\delta^{13} \mathrm{C}$ values throughout the section are probably due to local climate fluctuations, eustatic factors, and weathering, as well as differential isotopic fractionation within biomes and between different parts of individual plants. In the present study the $\delta^{13} \mathrm{C}$ data did not provide any prominent negative isotopic excursion peaks hence no definitive evidence of early Paleogene hyperthermal events in the Giral Lignite Mine succession was available.

It has been suggested that the early arrival of the Barmer region of the moving Indian plate towards the Reunion Plume is consistent with the presence of $68 \mathrm{Ma}$ aged basaltic rocks as the basement of Barmer Basin in subsurface (Basuet al., 1993; Compton, 2009). In many of subsurface wells in Barmer Basin, the Deccan volcanics are overlain by a sandstone facies known as Fathehgarh Formation dated as late Maastrictian - early Palaeocene (Compton, 2009). However, inadequate biostratigraphic framework and paleoenvironments of the overlying Barmer Hill, Dharvi, Dungar, Thumbli and Akli Formations continue to hamper correlation of different lithofacies in various rift basins of Barmer region. The present study, for the first time, provides a compelling basis for precise biostratigraphic age assignment (Danian-Thanetian) of the Giral Lignite Mine succession contrary to the late Palaeocene-early Eocene time bracket proposed by the earlier workers.

\section{Conclusions}

1. Dinoflagellate cysts and palynological study were carried out on the $38 \mathrm{~m}$ lignite bearing succession of open cast Giral
Mine, Barmer Basin, Rajasthan for the construction of biostratigraphic framework and depositional set up.

2. The LAD of Phelodinium tricuspe, Cerodinium striatum and Trithyrodinium evittii dinoflagellate cysts at $1.5 \mathrm{~m}$ from the base in Unit 1 suggested Danian Age. LAD of Damassadinium californicum and Carpatella cornuta at $7.8 \mathrm{~m}$ from the base indicate Danian-Selandian boundary at the top of Unit 1.

3. FAD of Kenleyia complex, Muratodinium fimbriatum, Turbiosphaera filosa and T. galatea at the top of Unit 3 suggests Selandian-Thanetian boundary.

4. Based on the dinoflagellate cysts, two Eustatic MFS one at 60.7 Ma at close to Danian-Selandian boundary another at 57.9 Ma in the basal Thanetian have been identified.

5. Five depositional Units have been identified for the Giral Lignite Mine succession based on the lithological charcteristics, distribution pattern of dinoflagellate cysts, mangrove pollen and terrestrial pollen. Unit 1 (lower $7.8 \mathrm{~m}$ ) is a transgressive deposit formed in an open bay setting during rise in the relative sea level representing the Transgressive Systems Tract (TST). Unit 2 (16.5 m) consists of 5-6 laterally occurring lignite bands deposited during decrease of sea level and increased detritus supply in essentially salt marsh environment during Highstand Systems Tract (HST). Unit 3 (3.42 $\mathrm{m}$ ) is shallow marine facies of Thanetian age deposited in a restricted setting represents a Transgressive Systems Tract. Unit $4(.9 \mathrm{~m})$ is marked by a return to coastal marsh depositional conditions, representing early Highstand Systems Tract. The erosional surface at the top of Unit 4 is interpreted as a Sequence Boundary. Unit $5(9.3 \mathrm{~m})$ is highly oxydized and is devoid of any organic matter content.

6. The present study provides a biostratigraphic age assignment (Danian-Thanetian) of the Giral Lignite Mine succession contrary to the late Palaeocene-early Eocene time bracket proposed by the earlier workers.

\section{Acknowledgments}

Authors are thankful to BSIP for providing facility. Thanks are also expressed to Ms Sandhya Singh for the processing of samples and slide preparation for dinoflagellate cysts.

\section{References}

Antolinez Delgado, H., and Oboh Ikuenobe, F.E., 2007, New species of dinoflagellate cysts from the Paleocene of the Anambra Basin, Southeast Nigeria. Palynology, v. 31, pp.53-62, https://doi.org/ 10.1080/01916122.2007.9989634.

Basu, A.R., Renne, P.R., Das Gupta, D.K., Teichmann, F., and Poreda, R.J., 1993, Early and late alkali igneous pulses and a high-3 He plume origin for the Deccan flood basalts. Science, v. 261, pp. 902-906, doi: 10.1126/science.261.5123.902.

Bladon, A.J., Clarke, S.M., Burley, S.D., Whiteley, N., Kothari, V., and Mohapatra, P., 2014, Structural inheritance in the Barmer Basin, India: Its influence on early-stage rift evolution and structural geometries. AAPG 2014 Annual Convention and Exhibition, Houston, Texas.

Bijl, P.K., Pross, J., Warnaar, J., Stickley, C.E., Huber, M., Guerstein, R., Houben, A.J., Sluijs, A., Visscher, H., and Brinkhuis, H., 2011. Environmental forcings of Paleogene Southern Ocean dinoflagellate biogeography. Paleoceanography, v. 26, pp. 1-12, doi:10.1029/2009PA001905. 
Biswas, S. K. 1992. Tertiary stratigraphy of Kutch. Journal of the Palaeontological Society of India, v. 37 pp. 1-29.

Bladon, A.J., Burley, S.D., Clarke, S.M., and Beaumont, H., 2015, Geology and regional significance of the Sarnoo Hills, eastern rift margin of the Barmer Basin, NW India. Basin Research, v. 27, pp. 636-655, doi.org/10.1111/bre.12093.

Bowman, V.C., Francis, J.E., Riding, J.B., Hunter, S.J., and Haywood, A.M., 2012, A latest Cretaceous to earliest Paleogene dinoflagellate cyst zonation from Antarctica, and implications for phytoprovincialism in the high southern latitudes. Review of Palaeobotany and Palynology, v. 171, pp. 40-56, doi.org/10.1016/ j.revpalbo.2011.11.004.

Bowman, V., Ineson, J., Riding, J., Crame, J., Francis, J., Condon, D., Whittle, R., and Ferraccioli, F., 2015, The Paleocene of Antarctica: Dinoflagellate cyst biostratigraphy, chronostratigraphy and implications for the palaeo-Pacific margin of Gondwana. Gondwana Research, v. 38, pp. 132-148, https://doi.org/10.1016/ j.gr.2015.10.018.

Brinkhuis, H., Romein, A.J., Smit, J., and Zachariasse, J.W., 1994, Danian selandian dinoflagellate cysts from lower latitudes with special reference to the El Kef section, NW Tunisia. GFF, Stratigraphy of the Paleocene, v. 116, pp. 46-48, doi.org/10.1080/ 11035899409546146.

Brinkhuis, H., Sengers, S., Sluijs, A., Warnaar, J., and Williams, G.L., 2003, Latest Cretaceous to earliest Oligocene, and Quaternary dinoflagellate cysts from ODP Site 1172, East Tasman Plateau. In Proceedings of the Ocean Drilling Program, Scientific Results, v. 189, pp. 1-48.

Chatterjee, S., Scotese, C., and Bajpai, S., 2017, The restless Indian plate and its epic voyage from Gondwana to Asia: its tectonic, paleoclimatic and paleobiogeographic evolution. Geological Society of America, Special Paper529, pp. 147.

Compton, P.M., 2009, The geology of the Barmer Basin, Rajasthan, India, and the origins of its major oil reservoir, the Fatehgarh Formation. Petroleum Geoscience, v. 15, pp. 117-130, doi.org/ 10.1144/1354-079309-827.

Costa, L., Denison, C., and Downie, C., 1978, The Paleocene/Eocene boundary in the Anglo-Paris Basin. Journal of the Geological Society, v. 135, pp. 261-264.

Crouch, E.M., Willumsen, P.S., Kulhanek, D.K., and Gibbs, S.J., 2014, A revised Paleocene (Teurian) dinoflagellate cyst zonation from eastern New Zealand. Review of Palaeobotany and Palynology, v. 202, pp. 47-79, https://doi.org/10.1016/j.revpalbo. 2013.12.004.

Dastas, N., Chamberlain, J., and Garb, M., 2014, CretaceousPaleogene dinoflagellate biostratigraphy and the age of the Clayton Formation, southeastern Missouri, USA. Geosciences, v. 4, pp. 1-29, doi.org/10.3390/geosciences4010001.

Davey, R.J., 1969, Some dinoflagellate cysts from the Upper Cretaceous of northern Natal, South Africa. pp. 1-23.

Dolson, J., Burley, S.D., Sunder, V.R., Kothari, V., Naidu, B., Whiteley, N.P., Farrimond, P., Taylor, A., Direen, N., and Ananthakrishnan, B., 2015, The discovery of the Barmer Basin, Rajasthan, India, and its petroleum geology Barmer Basin Petroleum Geology, India. AAPG Bulletin, v. 99, pp. 433-465, doi.org/10.1306/10021414045.

Firth, J.V., 1987, Dinoflagellate biostratigraphy of the Maastrichtian to Danian interval in the US Geological Survey Albany core, Georgia, USA. Palynology, v. 11, pp. 199-216, doi.org/10.1080/ 01916122.1987.9989328.

Fitzsimmons, R., Buchanan, J., and Izatt, C., 2005, The role of outcrop geology in predicting reservoir presence in the Cretaceous and Paleocene successions of the Sulaiman Range, Pakistan. AAPG bulletin, v. 89, pp. 231-254, https://doi.org/10.1306/ 08040403083.

Garg, R., Ateequzzaman, K., Prasad, V., Tripathi, S.K.M., Singh, I.B., Jauhri, A.K., and Bajpai, S., 2008, Age-diagnostic dinoflagellate cysts from the lignite-bearing sediments of the Vastan lignite mine,
Surat District, Gujarat, western India. Journal of the Palaeontological Society of India, v. 53, pp. 99-105.

Garg, R., Prasad, V., Thakur, B., Singh, I.B., and KhowajaAteequzzaman, 2011. Dinoflagellate cysts from the Naredi Formation, southwestern Kutch, India: implication on age and palaeoenvironment. Journal of the Palaeontological Society of India, v.56, pp. 201-218.

Guasti, E., Kouwenhoven, T.J., Brinkhuis, H., and Speijer, R.P., 2005, Paleocene sea-level and productivity changes at the southern Tethyan margin (El Kef, Tunisia). Marine Micropaleontology, v. 55, pp. 1-17, https://doi.org/10.1016/j.marmicro.2005.01.001.

Hardenbol, J.A.N., Thierry, J., Farley, M.B., Jacquin, T., De Graciansky, P.C., and Vail, P.R., 1998, Mesozoic and Cenozoic sequence chronostratigraphic framework of European basins. SEPM Special Publication No. 60.

Hansen, J.M., 1977, Dinoflagellate stratigraphy and echinoid distribution in Upper Maastrichtian and Danian deposits from Denmark. Bulletin of the Geological Society of Denmark, v. 26, pp. 1-26.

Heilmann Clausen, C., 1994, Review of Paleocene dinoflagellates from the North Sea region. GFF, v. 116, pp. 51-53, doi.org/ $10.1080 / 11035899409546149$.

Helby, R., Morgan, R., and Partridge, A.D., 1987, A palynological zonation of the Australian Mesozoic. In: Jell, P.A. (editor), Studies in Australian Mesozoic palynology. Memoir of the Assocation of Australasian Palaeontologists, v. 4, pp. 1-94.

Kaila, K.L., Tewari, H.C., Krishna, V.G., Dixit, M.M., Sarkar, D., and Reddy, M.S., 1990, Deep seismic sounding studies in the north Cambay and Sanchor basins, India. Geophysical Journal International, v. 103, pp. 621-637, doi.org/10.1111/j.1365246X.1990.tb05676.x.

Kelly, M.J., Najman, Y., Mishra, P., Copley, A., and Clarke, S., 2014, The potential record of far-field effects of the India-Asia collision: Barmer Basin, Rajasthan, India. 29 $9^{\text {th }}$ Himalaya-Karakoram-Tibet Workshop, pp. 80-81.

Kurita, H., and McIntyre, D.J., 1995, Paleocene dinoflagellates from the turtle mountain formation, southwestern Manitoba, Canada. Palynology, v. 19, pp. 119-136. doi.org/10.1080/01916122.1995. 9989455.

Iakovleva, A.I., 2011, Palynological reconstruction of the Eocene marine palaeoenvironments in south of Western Siberia. Acta Palaeobotanica, v. 51, pp. 229-248.

Lyck, J.M., and Stemmerik, L., 2000, Palynology and depositional history of the Paleocene? Thyra Ø Formation, Wandel Sea Basin, eastern North Greenland. Geology of Greenland Survey Bulletin, v. 187 , pp. 21-49.

Mudge, D.C., and Bujak, J.P., 2001, Biostratigraphic evidence for evolving palaeoenvironments in the Lower Paleogene of the Faeroe-Shetland Basin. Marine and Petroleum Geology, v. 18, pp. 577-590, doi.org/10.1016/S0264-8172(00)00074-X.

Mudge, D.C., and Bujak, J.P., 1996, Palaeocene biostratigraphy and sequence stratigraphy of the UK central North Sea. Marine and Petroleum Geology, v. 13, pp. 295-312, doi.org/10.1016/02648172(95)00066-6.

Nøhr-Hansen, H., 2003, Dinoflagellate cyst stratigraphy of the Palaeogene strata from the Hellefisk-1, Ikermiut-1, Kangâmiut1, Nukik-1, Nukik-2 and Qulleq-1 wells, offshore West Greenland. Marine and Petroleum Geology, v. 20, pp. 987-1016, doi.org/ 10.1016/S0264-8172(02)00116-2.

Nøhr-Hansen, H., and Dam, G., 1997, Palynology and sedimentology across a new marine Cretaceous-Tertiary boundary section on Nuussuaq, West Greenland. Geology, v. 25, pp. 851-854, doi.org/ 10.1130/0091-7613(1997)025<0851:PASAAN>2.3.CO;2.

Nøhr-Hansen, H., Nielsen, L.H., Sheldon, E., Hovikovski, J., and Alsen, P., 2011, Palaeogene deposits in north-east Greenland. Geological Survey of Denmark and Greenland. Bulletin, no. 23, pp. 61-64.

Oboh-Ikuenobe, F.E., Antolinez-Delgado, H., and Awad, W.K., 2017, 
Dinoflagellate cyst assemblages, biostratigraphy and paleoenvironment of a Paleocene-Early Eocene sedimentary succession in the northern Niger Delta Basin: Comparison with low, mid and high latitude regions. Palaeogeography, Palaeoclimatology, Palaeoecology, v. 481, pp. 29-43, doi.org/ 10.1016/j.palaeo.2017.05.020.

Parihar, V.S., Nama, S.L., and Mathur, S.C., 2016, Shallow Marine Trace Fossils from Mandai Formation of the Barmer Basin, District-Jaisalmer, Western Rajasthan, India. Journal of Ecosystems and Ecography, v. 6(189), pp.1-9.

Prasad, V., Singh, I.B., Bajpai, S., Garg, R., Thakur, B., Singh, A., Saravanan, N., and Kapur, V.V., 2013, Palynofacies and sedimentology-based high-resolution sequence stratigraphy of the lignite-bearing muddy coastal deposits (early Eocene) in the Vastan Lignite Mine, Gulf of Cambay, India. Facies, v. 59, pp. 737-761, DOI 10.1007/s10347-012-0355-8.

Powell, A.J., 1988, A modified dinoflagellate cyst biozonation for latest Palaeocene and earliest Eocene sediments from the central North Sea. Review of Palaeobotany and Palynology, v. 56, pp. 327-344, doi.org/10.1016/0034-6667(88)90064-4.

Powell, A.J., 1992, Dinoflagellate cysts of the Tertiary System. A Strtatigraphic Index of Dinoflagellate Cysts, pp. 155-251.

Quattrocchio, M.E., and Sarjeant, W.A., 2003, Dinoflagellates from the Chorrillo Chico Formation (Paleocene) of southern Chile. Ameghiniana, v. 40, pp. 129-153.

Rana, R.S., Kumar, K., Singh, H., and Rose, K.D., 2005, Lower vertebrates from the late palaeocene-earliest eocene Akli formation, giral lignite mine, Barmer District, western India. Current Science, v. 89(9), pp.1606-1613.

Schmitz, B., Alegret, L., Apellaniz, E., Arenillas, I., Aubry, M.P., Baceta, J.I., Berggren, W.A., Bernaola, G., Caballero, F., Clemmensen, A., Dinares-Turell, J., Dupuis, C., Heilmann-Clausen, C., Knox, R., Martin-Rubio, M., Molina, E., Monechi, S., Ortiz, S., OrueEtxebarria, X., Payros, A., Petrizzo, M.R., Pujalte, V., Speijer, R., Sprong, J., Steurbaut, E., and Thomsen, E., 2008, Proposed Global Stratotype Sections and Points for the bases of the Selandian and Thanetian stages (Paleocene Series) 52.

Sharma, K.K., 2007, KT magmatism and basin tectonism in western Rajasthan, India, results from extensional tectonics and not from Réunion plume activity. Special Papers Geological Society of America, no.430, pp. 775-784.

Singh, N.P., 2007, Cenozoic Lithostratigraphy of the Jaisalmer Basin, Rajasthan. Journal of Palaeontological Society of India, v. 52 (2), pp 129-154.

Slimani, H., Louwye, S., and Toufiq, A., 2010, Dinoflagellate cysts from the Cretaceous-Paleogene boundary at Ouled Haddou, southeastern Rif, Morocco: biostratigraphy, paleoenvironments and paleobiogeography. Palynology, v. 34, pp. 90-124, doi.org/ 10.1080/01916121003629933.

Sluijs, A., Brinkhuis, H., Crouch, E.M., John, C.M., Handley, L., Munsterman, D., Bohaty, S.M., Zachos, J.C., Reichart, G.J., Schouten, S., and Pancost, R.D., 2008, Eustatic variations during the Paleocene Eocene greenhouse world. Paleoceanography, v. 23, pp. 1-18, doi:10.1029/2008PA001615.

Sluijs, A., Bijl, P.K., Schouten, S., Röhl, U., Reichart, G.J., and Brinkhuis, H., 2011, Southern ocean warming, sea level and hydrological change during the Paleocene-Eocene thermal maximum. Climate of the Past, v. 7, pp. 47-61.

Speijer, R.P., 2003, Danian-Selandian sea-level change and biotic excursion on the southern Tethyan margin (Egypt). Special PapersGeological Society of America, pp. 275-290.

Steurbaut, E., and Sztrákos, K., 2008, Danian/Selandian boundary criteria and North Sea Basin-Tethys correlations based on calcareous nannofossil and foraminiferal trends in SW France. Marine Micropaleontology, v. 67, pp. 1-29. doi.org/10.1016/ j.marmicro.2007.08.004

Sudhakar, R., Basu, D.N., 1973, A reappraisal of the Paleogene stratigraphy of southern Cambay basin. Bulletin Oil and Natural Gas Commission, v.10, 55-76

Tripathi, S.K.M., Kumar, M., and Srivastava, D., 2009, Palynology of lower palaeogene (Thanetian-Ypresian) coastal deposits from the Barmer Basin (Akli Formation, Western Rajasthan, India): palaeoenvironmental and palaeoclimatic implications. Geologica Acta, v. 7, pp. 147-160, doi: 10.1344/105.000000275.

Vasilyeva, O.N., 2013, Paleogene dinocysts from the Eastern Caspian Depression (the Uspenskaya SP-1 Well, Kazakhstan). Lithosphere, v. 1, pp. 102-127.

Williams, G.L., Brinkhuis, H.M.A.P., Pearce, M.A., Fensome, R.A., and Weegink, J.W., 2004, Southern Ocean and global dinoflagellate cyst events compared: index events for the Late Cretaceous-Neogene. In Proceedings of the Ocean Drilling Program, Scientific Results, v. 189, pp. 1-98.

Willumsen, P.S., 2003, Marine Palynology across the CretaceousTertiary Boundary in New Zealand. Palynology, v. 27, p. 268.

Willumsen, P.S., and Vajda, V., 2010, A new early Paleocene dinoflagellate cyst species, Trithyrodiniumpartridgei: its biostratigraphic significance and palaeoecology. Alcheringa, v. 34, pp. 523-538, https://doi.org/10.1080/03115518.2010.519258.

Yepes, O., 2001, Maastrichtian Danian dinoflagellate cyst biostratigraphy and biogeography from two equatorial sections in Colombia and Venezuela. Palynology, v.25, pp.217-249,https:/ /doi.org/10.1080/01916122.2001.9989561.

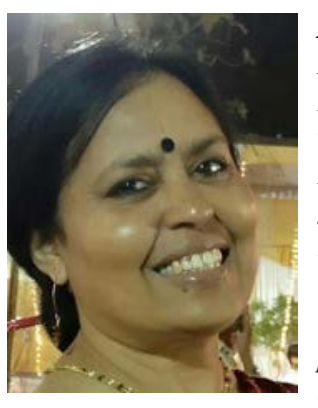

Dr. Vandana Prasad is a Marine Micropalaeontologist at the Birbal Sahni Institute of Palaeosciences. Dr. Vandana's various researchintrests include: Evolutionary biology (early history of grasses); High resolution biostratigraphy, biotic turnover, paleoenvironment and relative sea level change during Late Cretaceous-Early Palaeogene; Quaternary palaeoclimate studies using dinoflagellate cysts, Palynofacies and Phytolith proxies. Dr. Prasad is presently the Director at Birbal Sahni Institute of Paleosciences, Lucknow.

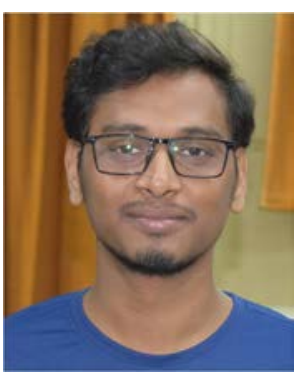

Dr. Prem Raj Uddandam is a post doctoral fellow at Department of Geology of Banaras Hindu University. He received his $\mathrm{PhD}$ in 2017 from BirbalSahni Institute of Palaeosciences \& Kumaun University. His research interests include: taxonomy of late Quaternary dinoflagellate cysts; applications of dinoflagellate cysts as indicators of surface hydrography and productivity related to Asian monsoon fluctuations in Northern Indian Ocean; high-resolution palaeoceanographic reconstructions using sedimentary archives; and Cenozoic dinoflagellate cyst biostratigraphy, paleogeography.

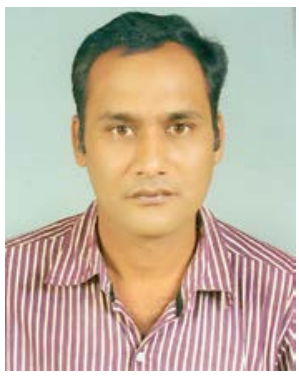

Dr. Shailesh Agrawal, Ph.D., is a Scientist at the BirbalSahni Institute of Palaeosciences, Lucknow, India. He has a special interest in bulk and compoundspecific stable isotope approaches. He has been working on the stable isotopic characterization of modern plants as well as surface soil/sediments samples of the Gangetic plain, central India and Himalayan region for the last 12 years. Along with this, he is using stable isotope ratio as a proxy (mainly carbon, nitrogen, hydrogen and oxygen isotopes) to decipher palaeoclimate condition and its effect on vegetation in different geological time scale. 